\title{
The Effects of Blended Learning on Elementary School Students' Creativity and Activeness
}

\author{
Miskiah", Yoyon Suryono, Ajat Sudrajat \\ Yogyakarta State University, Indonesia
}

Received June 11, 2020; Revised July 22, 2020; Accepted August 25, 2020

\section{Cite This Paper in the following Citation Styles}

(a): [1] Miskiah, Yoyon Suryono, Ajat Sudrajat , "The Effects of Blended Learning on Elementary School Students' Creativity and Activeness," Universal Journal of Educational Research, Vol. 8, No. 9, pp. 3958 - 3964, 2020. DOI: 10.13189/ujer.2020.080920.

(b): Miskiah, Yoyon Suryono, Ajat Sudrajat (2020). The Effects of Blended Learning on Elementary School Students' Creativity and Activeness. Universal Journal of Educational Research, 8(9), 3958 - 3964. DOI: 10.13189/ujer.2020.080920.

Copyright $\bigcirc 2020$ by authors, all rights reserved. Authors agree that this article remains permanently open access under the terms of the Creative Commons Attribution License 4.0 International License

\begin{abstract}
Creativity is one of the important components of success in 21st-century learning. Creativity needs to be developed and taught in the classroom. This study was conducted to know the difference in the effect of blended learning on students' creativity and activeness. This study also aimed to find out the significant improvement on students' creativity and activeness in elementary school. This study is of a quasi-experimental type with a non-equivalent comparison group design. The research subjects were fifth-grade students (32 students as experimental groups and 29 students as a control group) of public elementary schools in Bantul Regency, SDN Kasihan, and SDN Kalipucang, in the academic year 2019/2020. Rubric for Creativity (RC) and Rubric for Activeness (RA) were administered for pretest and posttest. The duration of the experimental learning was three meetings and one meeting for examination. The data analysis technique used independent samples t-tests and paired samples t-tests at the significance level of .05 . The results of the study show that there was a significant difference in creativity between the experimental group (applying blended learning) and the control group (applying scientific learning). Experimental group students had higher scores on both variables compared to their counterparts. Thus, it can be concluded that blended learning is effective in improving creativity and activeness of elementary school students.
\end{abstract}

Keywords Blended Learning, Creativity, Activeness

\section{Introduction}

The skills needed in the $21^{\text {st }}$ century is different from those needed in the previous century [1], one of the keys to successful learning in the $21^{\text {st }}$ century being creativity. Students need to be creative and flexible to learn and understand knowledge, so creative thinking is critical for students [2]. Creativity is seen as a construct that needs to be developed and taught in the classroom. This is because creativity is associated with academic achievement, divergent thinking, and self-efficacy [3]. Therefore, many countries promote creativity to develop the next generation of innovators [4]. In other words, students must be trained to develop creativity to the fullest. Teachers have a big role to encourage the ability of creativity, and therefore they are also required to be creative, be open to creative ideas, and support the creative process [5]. Thus, teachers' support is needed to find ways and confidence to express their imagination. This is needed to develop students' intellectual capacities and to lead them closer to self-actualization. By including thought processes in all areas of content, teachers can provide the $21^{\text {st }}$-century life skills in the students' creative thinking and production [6].

Teaching in the $21^{\text {st }}$ century means teaching the $21^{\text {st }}$-century generation. Activities are a principle or foundation that is very important in teaching and learning interactions. The characteristics of active students are shown by students being more involved in activities such as listening, reading, discussing and writing, and development of skills. According to Bell and Kahrhoff [7], 
stating that active learning is a process where students are actively involved in the development of understanding facts, ideas, and skills through the completion of tasks and learning activities. Previous research conducted by Fitzsimons [8] found that students showed an interest in learning when learning was actively developed. Active learning is a deliberate opportunity for students to be involved in the learning process through movement, reflection, and discussion.

One way to activate students is by integrating active learning strategies with ICT media to bottle up learning into a more interesting, enjoyable, and effective activity for teachers and students so that learning becomes more interactive. This is also confirmed by Vickery [9] that Toolboxes in ICT can provide opportunities for students to become active learners. ICT-based learning is now known as e-learning. It refers to the use of advanced information and communications technology in the learning process, where sophisticated technology consists of electronic media [10]. In primary schools, the use of pure e-learning is not possible because teachers and students are required to carry out face-to-face activities in class. Therefore, the combination of face-to-face learning models in class with the learning model based on e-learning is one of the efforts to cope with these problems. This combined learning model is known as the blended learning model. This agrees with Koohang [11], stating that blended learning is defined as a mix of traditional face-to-face instructions and still conducted face-to-face in the classroom so that the assessment of students' affective competencies, inculcation of values, and monitoring of moral growth can still be carried out by the teacher, while the use of e-learning will be able to facilitate students during the learning process, thereby obtaining maximum learning benefits.

Previous research conducted by Saliba et al. [12] found that blended learning can increase access and flexibility for students and the level of the students' learning activeness, creativity, achievement, and experience to be better. While for teaching staff, blended learning can improve teaching and class management practices. This is also supported by the results of Hallam's [13] research that using blended learning posttest is better than using traditional models. Collaborative situations in an online environment have a positive effect on students' learning outcomes. Thus, this research aimed to develop and investigate the impact of blended learning in elevating the learning creativity and activeness of fifth-grade elementary school students.

\subsection{Blended Learning, Creativity, and Activeness}

One learning model that utilizes ICT is the blended learning model. There are many educational researchers recommending blended learning as a learning solution [14-17] for students, trainers, and ICT staff [18-19]. According to Graham [20], blended learning is a combination of face-to-face learning and computer approaches. Garrison and Vaughan [21] also teach blended learning as a mixed learning process between face-to-face and online learning as a unique learning experience. Meanwhile, Krause [22] states that blended learning is a learning process that is conveyed through different teaching models and learning styles. This was also confirmed by Utomo, Sumarmi, and Susilo [23] that the use of e-learning teaching materials can improve the quality of student learning. That is, teaching materials are delivered not only from teachers and books, but also through e-learning that will enrich the references and information. With blended learning, we will find ways to achieve learning objectives and obtain more meaningful teaching and learning experiences.

The activeness of students in learning is an important element for the success of the teaching and learning process. Through blended learning, activities and creativity of students will develop with a variety of interactions that provide opportunities for the students to develop individual abilities without leaving social interaction in the classroom. With this system students are more active in learning, while the teacher acts as a facilitator. The implementation of blended learning will also encourage students to be more active in participating in learning so that it can lead to high creativity [12].

\subsection{Research Questions}

The research questions are:

a). Are there significant differences in scores on creativity and activeness between the students in the experimental and control classes before and after treatment?

b). Is there any significant increase in scores on creativity and activeness between the students in both classes before and after the intervention?

\section{Materials and Methods}

\subsection{Research Design}

This research used the non-equivalent control group pretest-posttest design. This design is one of the strongest quasi-experimental research designs [24]. In this research, the researchers gave pretest and posttest to students in the experimental and control classes. After the treatment, the researchers compared the conditions before and after treatment in the two classes. The dependent variables were students' creative thinking and activeness.

\subsection{Participants}

The participants consisted of 61 fifth-grade students (aged 11-12 years) from two public schools in Yogyakarta, Indonesia. The experimental group consisted of 32 students 
(17 males and 15 females) from Kasihan Elementary School and 29 students (15 males and 14 females) from Kalipucang Elementary School. The experimental group was taught using a blended learning strategy, and the control group was taught by the conventional method. In this research, all students had similar characters and abilities because the schools had no superior nor regular class and both had three classes for each major. All students in both groups were taught by 2 female teachers (aged 40-45 years) who had similar teaching experiences (teaching for more than 10 years). The teachers held a Bachelor's degree from a local university. Furthermore, all teachers were trained to apply different methods before treatment. This research was conducted from August to October 2019.

\subsection{Instruments}

\subsubsection{Rubric for Creativity (RC)}

To evaluate the creativity and activeness of the students in terms of classroom learning and e-learning media, RC was used. Indicators of creativity were adopted from Cropley [25] concerning the scoring rubric. The maximum and minimum scores obtained by each student were 20 and 0 .
The rubric was tested on 30 fifth grade students at Kasongan Elementary School after obtaining expert judgments. The results of the trial were analyzed using the Content Validity Ratio (CVR) equation. Rubric validity test results were declared valid if the $r$ count was equal to or greater than the $r$ table with a significant tariff of $5 \%$. All indicators in the rubric were declared valid as presented in table 1.

Table 1. Validity Instruments of Creative Thinking abilities

\begin{tabular}{|c|c|c|c|c|}
\hline Sub-scales & $\mathrm{r}_{\text {count }}$ & $\mathrm{r}_{\text {table }} 5 \%(\mathrm{n}=32)$ & $p$ & criteria \\
\hline Fluency & .732 & 0.349 & 0.000 & Valid \\
\hline Flexibility & .589 & 0.349 & 0.001 & Valid \\
\hline Originality & .801 & 0.349 & 0.000 & Valid \\
\hline Elaboration & .469 & 0.349 & 0.009 & Valid \\
\hline
\end{tabular}

\subsubsection{Rubric for Activeness (RA)}

To evaluate the students' activeness based on aspects of visual activities, oral activities, listening activities, writing activities, drawing activities, metric activities, mental activities, and emotional activities, RA was used. Indicators of activeness were adopted from Paul D. Dieruch [26] regarding the activeness rating grid (see table 2).

Table 2. Activeness Assessment Grid

\begin{tabular}{|c|c|c|}
\hline Aspects & Indicators & Score \\
\hline Visual activities & $\begin{array}{l}\text { Reading instructions on the sheet, student activities, paying attention to } \\
\text { explanations, reading books, digital literacy, viewing pictures and videos, } \\
\text { and observing demonstrations }\end{array}$ & 5 \\
\hline Oral activities & $\begin{array}{l}\text { Asking questions, answering questions verbally, expressing opinions, giving } \\
\text { advice, discussing, presenting results, and conducting interviews }\end{array}$ & 5 \\
\hline Listening activities & $\begin{array}{l}\text { Listening to the teacher's explanation, listening to the presentation of } \\
\text { materials, listening to group discussions, listening to presentations from } \\
\text { other students online, and filling out the questionnaire }\end{array}$ & 5 \\
\hline Writing activities & $\begin{array}{l}\text { Taking notes on important materials during presentations, discussions, } \\
\text { making reports, making summaries, expressing opinions in discussions, } \\
\text { doing assignments and tests online, and filling out the questionnaire }\end{array}$ & 5 \\
\hline Drawing activities & Drawing illustrations, graphs, diagrams, and mind maps & 5 \\
\hline Metric activities & $\begin{array}{l}\text { Conducting experiments, conducting simulations or games, visiting the } \\
\text { surrounding environment, making observations, and and uploading } \\
\text { observations in the e-learning media }\end{array}$ & 5 \\
\hline Mental activities & $\begin{array}{l}\text { Giving responses, reflecting on their learning experiences, assessing their } \\
\text { own learning outcomes, analyzing, and providing solutions to } \\
\text { problem-solving }\end{array}$ & 5 \\
\hline Emotional activities & $\begin{array}{l}\text { Following the learning process with enthusiasm, being full of energy, and } \\
\text { persistently learning difficult materials }\end{array}$ & 5 \\
\hline
\end{tabular}


RA was tested on 32 students at Bibis Elementary School. The results were categorized as valid since the $r_{\text {tabel }}$ was .349. Table 4 showed that there were 5 valid items of 8 items in total. Therefore, 5 questions were used to measure students' activeness in this research.

Table 3. Validity of RA.

\begin{tabular}{|c|c|c|c|c|}
\hline Sub-scales & rarithmetic & $\begin{array}{c}\text { rtable 5\% } \\
(\mathrm{n}=32)\end{array}$ & $\mathrm{p}$ & Criteria \\
\hline $\begin{array}{c}\text { Visual } \\
\text { activities }\end{array}$ & .651 & .349 & .000 & Valid \\
\hline $\begin{array}{c}\text { Oral } \\
\text { activities }\end{array}$ & .029 & .349 & .880 & Invalid \\
\hline $\begin{array}{c}\text { Listening } \\
\text { activities }\end{array}$ & .644 & .349 & .000 & Valid \\
\hline $\begin{array}{c}\text { Writing } \\
\text { activities }\end{array}$ & .112 & .349 & .557 & Invalid \\
\hline $\begin{array}{c}\text { Drawing } \\
\text { activities }\end{array}$ & .369 & .349 & .045 & Valid \\
\hline $\begin{array}{c}\text { Metric } \\
\text { activities }\end{array}$ & .319 & .349 & .085 & Invalid \\
\hline $\begin{array}{c}\text { Mental } \\
\text { activities }\end{array}$ & .355 & .349 & .054 & Valid \\
\hline $\begin{array}{c}\text { Emotional } \\
\text { activities }\end{array}$ & .404 & .349 & .027 & Valid \\
\hline
\end{tabular}

\subsubsection{Data Analysis}

Kolmogorov-Smirnov was used to test the normality of pre- and posttest data (sig $>.05)$. A paired samples t-test was used to analyze the creativity and activeness level. The increase in the pretest to posttest score was checked using $n$-gain formula (Hake, 1999); high, $g \geq .70$; moderate, .70> $g \geq .30$; and low $g<.30$. Besides, an independent samples t-test was used to investigate whether there were differences in creativity and activeness between the experimental and control groups. The t-test was performed using the SPSS version 22 program at the significance level of .05 .

\section{Results and Discussion}

\subsection{Results}

\subsubsection{Influence on Students' Creativity}

A paired samples t-test was used to answer the question "are there significant differences in scores on creativity and activeness between students in the experimental and control classes?" The results are presented in Table 4.

Table 4. Creativity Pretest and Posttest Scores

\begin{tabular}{|c|c|c|c|c|}
\hline \multirow{2}{*}{ Groups } & \multicolumn{2}{|c|}{ Average } & \multirow{2}{*}{ Gain } & \multirow{2}{*}{ Criteria } \\
\cline { 2 - 3 } & Pretest & Posttest & & \\
\hline Control & 50.86 & 60.17 & .19 & Low \\
\hline Experimental & 50.93 & 77.18 & .54 & Medium \\
\hline
\end{tabular}

Table 4 illustrates that the pretest scores in the control class and experimental class were almost the same. After treatment, both classes had improved. Scores in the experimental class increased sharply compared to the control class. The increase in scores in the experimental class was 26.25 with a gain of .54. Thus, it can be concluded that the creativity of the experimental class was higher than that of the control class.

An independent t-test was conducted to determine whether there were differences in creativity scores between the control class and the experimental class (see Table 5).

Table 5. Independent t-test results on creativity

\begin{tabular}{|c|c|c|c|c|c|}
\hline & Groups & $\mathrm{A}$ & $\mathrm{SD}$ & $\mathrm{df}$ & $\mathrm{p}$ \\
\hline \multirow{3}{*}{ Pre-test } & Control & 50.86 & 9.240 & \multirow{2}{*}{59} & \multirow{2}{*}{.134} \\
\cline { 2 - 5 } & Experimental & 50.93 & 9.053 & & \\
\hline \multirow{2}{*}{ Post-test } & Control & 60.17 & 9.795 & \multirow{2}{*}{59} & \multirow{2}{*}{.000} \\
\cline { 2 - 5 } & Experimental & 77.18 & 9.135 & & \\
\hline
\end{tabular}

From Table 5, it can be seen that the $p$-value on the pretest score was greater than 0.05 . This shows that there was no difference in creativity between students taught using blended learning and those taught using traditional teaching strategy before treatment $(p=.134)$. After application, there was a significant difference in creativity scores between students in the experimental and control classes $(p=.000)$. The scores of experimental group students $(A=77.18$; $S D=9.135)$ were higher than those of control group students $(A=60.17 ; S D=9.795)$.

\subsubsection{Influence on Students' Activeness}

A paired samples t-test was used to answer the question "are there significant differences in scores on creativity and activeness between students in the experimental and control classes?" The results are presented in Table 6.

Table 6. Pre- and Posttest Scores on Students' Activeness

\begin{tabular}{|c|c|c|c|c|}
\hline \multirow{2}{*}{ Groups } & \multicolumn{2}{|c|}{ Average } & \multirow{2}{*}{ Gain } & \multirow{2}{*}{ Criteria } \\
\cline { 2 - 3 } & Pretest & Posttest & & \\
\hline Control & 50.17 & 61.82 & .22 & Low \\
\hline Experimental & 50.75 & 79.93 & .54 & Medium \\
\hline
\end{tabular}

As can be seen in Table 6 there was no difference in activeness between students in the experimental and control classes at the beginning of the intervention. After treatment, there was an increase in students' activeness scores in both classes in favor of experimental group students. The increase in scores in the experimental class was 29.18 (gain $=0.54$ ), while that in the control class was 11.65 (gain $=0.22$ ). It can be concluded that the activeness of the students in the experimental class increased higher than that in the control class.

Then, to find out whether there was a difference in activeness between students in the control and experimental classes, an independent t-test was conducted. 
Table 7. Independent t-test Results for Activeness

\begin{tabular}{|c|c|c|c|c|c|}
\hline & Groups & $\mathrm{A}$ & $\mathrm{SD}$ & $\mathrm{df}$ & $\mathrm{p}$ \\
\hline \multirow{2}{*}{ Pre-test } & Control & 50.17 & 8.319 & \multirow{2}{*}{59} & \multirow{2}{*}{.331} \\
\cline { 2 - 5 } & Experimental & 50.75 & 8.617 & & \\
\hline \multirow{2}{*}{ Post-test } & Control & 61.82 & 7.949 & \multirow{2}{*}{59} & \multirow{2}{*}{.000} \\
\cline { 2 - 4 } & Experimental & 79.93 & 8.93 & & \\
\hline
\end{tabular}

As can be seen in Table 7, there was no significant difference in activeness scores between the blended learning class and conventional class before treatment $(p$ $=.331$ ). After the application, it found that there were significant differences in activeness scores between students in the experimental and control classes $(p=0.000)$. The mean posttest scores of experimental group students ( $A$ $=79.93 ; S D=9.461)$ were higher than those of control group students $(A=61.82 ; S D=7.949)$.

\subsection{Discussion}

After analyzing the effect of blended learning on students' creativity and activeness, the researchers found that blended learning could create new learning patterns and reduce students' boredom so that it can improve students' achievement. This finding is supported by the results of previous research conducted by Cobanoglu and Yurdakul [27], showing that blended learning has a positive effect on students' achievement. Furthermore, Sherman and Paz [28] state that information and communications technology is an important learning tool. Blended learning can engage students who have various learning styles by using a combined approach to meet diverse students' needs and enable teachers and students to improve their learning practices [29]. Shinde and Desmukh [30] also emphasize that blended learning helps students to develop better in the learning process under learning styles and preferences in learning as well as provides realistic practical opportunities for teachers and students to learn independently, be useful, and continue to develop.

Changes in scores of students' creativity can be seen from fluency, flexibility, originality, elaboration, and activeness. This means that the existence of blended learning could increase the effectiveness and creativity of the students in learning. This is in line with the opinion of Paavola, Lipponen, \& Hakkarainen, [31] stating that creativity is a process of building knowledge and learning through new technology or designed media. Students who have creativity will be better able to solve real problems adaptively because students can find more than one alternative solution [32]. Students who have creativity are also better able to recognize failures and difficulties, see a failure as a learning opportunity, then, develop, implement, and communicate new ideas to overcome these difficulties [33]. The characteristics of students who have creativity show that creativity is one of the important individual skills that students need to have. We believe that blended learning can be used as a learning model that has strong potentials to improve teaching and learning processes and can provide teachers and students with new and interesting experiences. Blended learning can also allow students to interact with learning resources widely and can access information flexibly without any limitation of time and place. As expressed by Aristovnik et al. [34], e-learning is effective because it eliminates distance. In a previous study, Barth and Bourke [22] suggest that blended learning expands the space and opportunities available for learning. Thus, blended learning is effective for increasing creativity and creating a pleasant learning atmosphere.

The paired samples t-test results show that the creativity scores of the students in the experimental group increased higher than those of their counterparts. This is possible for the joyfulness of learning because they could learn while playing so that students were free to express their creativity. Susan and Chris [35] argue that blended learning can make students more active and more creative. Blended learning also has a positive effect on students' performance, strengthens students' independence, and facilitates review of and control over learning [36]. This is supported by the many results of research showing that blended learning is more effective and has a positive effect compared to traditional learning models [36-38]. This is also supported by Harandi [39], who state that e-learning is a new pattern of education that is forced by scientific changes occurring in the world today due to the inability of traditional teaching strategies to compensate for these changes. Therefore, according to Zare et al. [40], e-learning is now considered one of the most important educational environments in the age of information.

Students' activeness also increased significantly after being intervened. This can be seen from the effects of visual activities, oral activities, listening activities, writing activities, drawing activities, metric activities, mental activities, and emotional activities on physical and psychological activities of the students. Blended learning allows students to become more involved in the learning process, creating a positive attitude towards learning and producing higher grades. Improvements in students' attitudes toward learning can be considered as outcomes in themselves, but also have an impact on the final grades achieved. According to Aristovnik et al. [34], blended learning allows students to learn anytime and anywhere. E-learning also helps improve learning and teaching, is more flexible, and reduces costs compared to traditional classes but does not replace traditional learning [20]. Therefore, blended learning is recommended by many educational researchers [14-17].

Previous research is similar, as stated by Vickery [10], in that one way to activate students is to use ICT. Hasan and Kazlaukas [41] in online research wrote that activity is a key term that means more than just being active; human activity is the goal and is carried out by a set of actions through the use of 'tools' which are not only physical but 
also psychological. B. Hamzah and Nurdin [42] explain that activating students in the learning process is that students are expected to be actively seen in learning activities to think, interact, do to try, find new concepts, or produce a work. Stephenn, Ellis, and Martlew [43] in their writing also explain that active learning can be realized by involving students in learning activities. They have the opportunity to engage and respond verbally through manipulating objects and physical actions, but their emphasis is on planning learning activities that are directed by the teacher. This is in line with the results of research by Gleason et al. [44] that active learning is an important component in education. By involving students in the learning process, they are better able to apply the knowledge they have gained. Students are expected to actively integrate knowledge, skills, attitudes, values, and behaviors so that they become capable students in their fields [44].

\section{Conclusions}

According to the obtained results, it has been concluded that students in the experimental class were more dominant in their creativity and activeness. After the intervention using blended learning, the scores of creativity and activeness of experimental class students increased compared to students in the conventional classes. We argue that blended learning is effective in increasing the creativity and activeness of elementary school students. This implies that teachers are encouraged to use blended learning to motivate students to learn more. This learning model successfully encourages students to be more active in learning. Therefore, students will be motivated to be more active and creative in terms of learning in the future.

This study provided some of the recommendations that the researchers formulated as follows. In this uncertain COVID-19 era, education have been significantly disrupted, requiring educators and learners to adapt to learning at a distance while aiming for normalcy. Teachers need to accommodate ICT to their teaching practices and use it in many different approaches and methods in the process of teaching and learning. Further research can utilize blended learning as a strategy to improve teaching and learning. Teachers also need to consider the students' ability and facilities before determining learning strategies because each student has different abilities and facilities; therefore, they must support each other to provide a positive influence on the development of students' creativity and activeness.

\section{Acknowledgments}

The authors thank the Religious Research, Development and Training Agency of the Ministry of Religious Affairs of the Republic of Indonesia which has given us support to conduct this research.

\section{REFERENCES}

[1] Tican, C., \& Deniz, S. Pre-service teachers' opinions about the use of 21st century learner and 21st century teacher skills. European Journal of Educational Research, 8(1), 181-197. doi: 10.12973/eu-jer.8.1.181. 2019.

[2] Hwang, W.-Y., Chen, N, -S., Dung, J.-J., \& Yang, Y.-L. Multiple representation skills and creativity effects on mathematical problem solving using a multimedia whiteboard system. Educational Technology and Science. 10(2), 191-212. 2007.

[3] Haase, J., Hoff, E. V., Hanel, P. H. P., \& Innes-Ker, A. A Meta-Analysis of the Relation between Creative Self-Efficacy and Different Creativity Measurements. Creativity Research Journal, 30(1), 1-16. 2018.

[4] Hadar, L. L., \& Tirosh, M. Creative Thinking in Mathematics Curriculum: An Analytic Framework. Thinking Skills and Creativity, 100585. Doi: 10.1016/j.tsc.2019.100585. 2019.

[5] Bakir, S., \& Oztekin, E. Creative thinking levels of preservice science teachers in terms of different variables. Journal of Baltic Science Education, 13(2), 231-242. 2014

[6] Thompson, T. Teaching creativity through inquiry service. Gifted Child Today, 40(1), 29-42. https://doi.org/10.1177/1076217516675863. 2017.

[7] Bell, D., \& Kahrhoff, J. Active learning handbook. Louis, Missouri: Copyright Webster University.2006.

[8] Fitzsimons, M. Engaging students’ Learning through Active Learning. Irish Journal of Academic Practice, 3(1), 13. 2014.

[9] Vickery, A. Developing Active Learning in the Primary Classroom. London: SAGE Publication Ltd. 2014.

[10] Thomas, J., \& Graham. Online teaching competencies in observational rubrics: What are institutions evaluating? Distance Education. 40(1), 114-132. 2019.

[11] Koohang, A. A learner-centered model for blended learning design. International Journal of Innovation and Learning, 6(1), 76-91. 2009.

[12] Saliba, G., Rankine, L., \& Cortez, H. Fundamentals of blended learning. University of Western Sydney. 2013. Retrieved January, 30, 2020.

[13] Hallam, J. M. Blended online learning versus traditional classroomlearning: A comparison of mathematics content mastery for high school students of homeowners and non-homeowners. Liberty University. 2015.

[14] Bereiter, C. Education and mind in the knowledge age. Hillsdale, NJ: Erlbaum. 2002.

[15] Garrison, R.R., Archer, W. \& Anderson, T. E-Learning in the 21st Century: A framework for research and practice. London: Routledge/Falmer. 2003.

[16] McLoughlin, C., \& Lee, M. J. Social software and 
participatory learning: Pedagogical choices with technology affordances in the Web 2.0 era. ICT: Providing choices for learners and learning. Proceedings ascilite Singapore, 664-675. 2007.

[17] Bonk, C.J., \& Graham, C.R. The Handbook of Blended Learning: Global Perspectives, Local Designs. New York: John Wiley \& Sons. 2012.

[18] A. Y. Alsabawy, A. Cater-Steell, J. Soar. Determinants of perceived usefulness of e-learning systems. Comput. Hum. Behav., 64, pp. 843-858. 2016.

[19] A. K. M. N. Islam. E-learning system use and its outcomes: moderating role of perceived compability. Telematics Inf., 33 (1), pp. 48-55. 2016.

[20] Graham, Charles R. Blended learning systems: Definition, current trends, and future directions. 2004.

[21] Garrison, D. R., \& Vaughan, N. D. Blended Learning in Higher Education: Framework, Principles, and Guidelines. San Francisco: Jossey-Bass. 2008.

[22] Bath, D., \& Bourke, J. Blended Learning. Australia: Griffith University. 2010.

[23] Utomo, D. S., Sumarmi., \& Susilo, S. Pengembangan Bahan Ajar E-Learning Berbasis Edmodo pada Materi Litosfer Kelas X SMA. Jurnal Pendidikan Geografi, 20(2), 1-8. 2015

[24] Johnson, R. B., \& Christensen, L. Educational Research: Quantitative, Qualitative, and Mixed Approaches (5th ed.). California: Sage Publication, Inc. 2014.

[25] Cropley, A. J. More ways than one: Fostering creativity. Greenwich: Ablex Publishing Corporation. 1997.

[26] Dierich, P. D. Active learning. Jakarta: Rineka Cipta. 2001.

[27] Cobanoglu, A. A. \& Yurdakul, B. The effect of blended learning on students' achievement, perceived cognitive flexibility levels and self-regulated learning skills. Journal of Education and Practice Vol. 5. No. 22. 2014.

[28] Sherman, C. K., \& Paz, D. L. S. (2012). Technology to facilitate the general education curriculum. In J. Aitken, J. Fairley, \& J. Carlson (Eds.). Communication Technology for Students in Special Education and Gifted Programs (pp. 26-33). Hershey, PA: IGI Global. Doi:10.40181978-1-60960-878-1.ch002. 2012.

[29] Huang, R., Ma, D., \& Zhang, H. Towards a design theory of blended learning curriculum. In International Conference on Hybrid Learning and Education (pp.66-78). Springer, Berlin, Heidelberg. 2008.

[30] Shinde, S. P. \& Deshmukh V. P. Blended learning methodology in school education. International Journal of Computing and Business Research (IJCBR) ISSN (Online): 2229-6166 Volume 3 Issue 2. 2012.

[31] Paavola, S., Lipponen, L., \& Hakkarainen, K. Models of innovative knowledge communities and three metaphors of learning. Review of Educational Research, Winter 2004. Vo. 74 No. 4. 557-576.2004.

[32] Svecova, V., Rumanova, L., \& Pavlovicova, G. Support of pupil's creative thinkingin mathematical education. Procedia - Social and Behavioral Sciences (116), 1715-1719. 2014.

[33] Griffin, P., Care, E., \& McGaw, B. The changing role of education and schools. In P. Griffin, B. McGraw \& E. Care (Eds.), Assessment and Teaching of 21st Century Skills (pp. 1-16). New York: Springer. 2012.

[34] Aristovnik, A., Tomazevic, N., Kerzic, D., Umek, L.The impact of demographic factors on selected aspects of e-learning in higher education. Int. J. Inf. Learn. Technol. 34 (2), 114-121. 2017.

[35] Susan, P., \& Chris, S. Maximizing competency education and blended learning. Inco Competency Works, New Yoek.2015.

[36] Boyle, T., Bradley, C., Chalk, P., Jones, R., \& Pickard, P. Using blended learning to improve student success rates in learning to program. Journal of Educational Media, 28 (2-3), 165-178. 2003.

[37] Bakeer, A. Students' attitudes towards implementing blended learning in teaching English in higher education institutions: A case of Al-Quds Open University. Int. J. Humanit. Soc. Sci. 8 (6), 131-139. 2018.

[38] Okaz, A. Integrating blended learning in higher education. Procedia - Social Behaviour Science. 186, 600-603. 2015.

[39] Harandi, S. Effects of e-learning on students' motivation. $3^{\text {rd }}$ International Conference on Leadership, Technology and Innovation Management. Procedia - Social Behaviour Science. 181, 423-430. 2015

[40] Zare, M., Sarikhani, R., Salari, M., Mansouri, V. The impact of e-learning on university students' academic achievement and creativity. Journal of Technical Education and Training. (JTET) 8 (1), 25-33. 2016.

[41] Hasan, H. \& Kazlauskas, A. Activity Theory: who is doing what, why and how. In H. Hasan (Eds.), being practical with theory: A window into Business research (pp.9-14). Wollongong. Australia: THEORI. 2014.

[42] B, Hamzah., \& Nurdin. Learn with the PAILKEM Approach. Jakarta: PT Bumi Aksara. 2011.

[43] Stephen, C., Ellis, J., \& Martlew, J. Taking active learning into the primary school: a matter of new practice? International Journal of Early Years Education, 18(4), 315-329. 2010.

[44] Gleason, B. L., Peeters, M. J., Resman-Targoff, B.H., Karr, S., McBane, S., Kelley, K., ...Denetclaw, T. H. An active learning strategies primer for achieving ability-based educational outcomes. American Journal of Pharmaceutical Education, 75(9), 1. 2011. 